\title{
Delimiting leisure and culture: Towards a new definition of leisure property
}

Recerved 25 November 2004

\begin{abstract}
Neil Ravenscroft
is principal research fellow at the Chelsea School, University of Brighton, having previously been reader in leisure management at the University of Surrey and reader in rural land management at the University of Reading. Neil is currently managing editor of Leisure Studies and a member of the editorial board of the Journal of Retail and Leisure Property. Neil has researched and written extensively on leisure and property, and has advised the Countryside Agency and DEFRA on matters relating to the leisure use of land and natural resources.
\end{abstract}

\section{Paul Gilchrist}

is research officer at the Chelsea School, University of Brighton, having previously been a graduate student in politics at Warwick University. Paul has a particular interest in heroism in sport (the subject of his $\mathrm{PhD}$ research) and in the micro politics of access to land for recreation. Paul has recently completed work for the South East England Cultural Consortium and Sussex Learning and Skills Council on determining the scope and employment impact of the cultural and creative industries.

\begin{abstract}
This paper argues that, while leisure has gained increasing recognition as a property sector, the definition of this sector has been narrowed to such an extent that it is now hard to distinguish from the retail sector. Using Pratt's cultural production model allied to the Standard Industrial Classification system, the paper suggests that, unlike retail, leisure activity represents a nexus between production, distribution, reproduction and consumption that is currently not reflected by common understandings of 'leisure property'.
\end{abstract}

\section{Keywords:}

leisure property, cultural production, industrial classification

Neil Ravenscroft Chelsea School University of Brighton Trevin Towers Gaudick Road Eastbourne BN20 7SP, UK Tel: +44 (o) 1273643889 E-mail: n.ravenscroft@brighton.ac.uk

\section{INTRODUCTION}

In its relatively short existence, the Journal of Retail and Leisure Property (and before it the Journal of Leisure Property) has helped establish the legitimacy of leisure, in particular, as an accepted subject for property research. While there certainly was research into leisure property prior to the publication of the Journal ${ }^{1}$ it tended not to appear in property research journals, ${ }^{2}$ or to appear as a specialist application of more general research. ${ }^{3}$ But, despite its increasing pedigree as a subject for research, little attempt has yet been made to determine the stance from which leisure is understood 
Leisure property

The concept of leisure as a potential occupier of space. ${ }^{4}$ As a consequence, little attention has been paid to defining the boundaries of 'leisure property', or how these relate to associated property types, such as culture, sport and, of course, retail.

Rather than attempt such a definitional project, it is apparent that the Journal describes leisure as a category of property in an inclusive manner, little distinguished from retail. For example, in the aims and scope of the Journal, specific reference is made to 'all types of retail and leisure property and the processes applied to them, including mixed-use developments, shopping centres, warehouse retailing, pubs, bars and restaurants, department stores, hotels, foodstore retailing, high street and retail parks ...'

In noting the dominance of retail uses in this list, it is apparent that 'leisure property' is regarded mainly as a mix of accommodation, food and beverage outlets, and as an adjunct or context for retail activities. With some notable exceptions, this is very much the territory within which leisure is understood, predicated broadly on outmoded classifications such as the Use Classes Order. ${ }^{5}$ This raises questions about the appropriateness of the term 'leisure', given that accommodation is conventionally understood as an element of tourism, while not all food and beverage outlets are necessarily understood to be a core part of a leisure offer. It also suggests that a question must be raised about the extent to which there exists a recognisable and meaningful understanding of the category 'leisure property', or whether it is largely a term coined loosely to represent 'unconventional' uses of (in this case mainly retail) property. This paper seeks to address this question, first by reviewing the construct of leisure and its relevance for describing property types, and then by proposing a broad (delimited) construct of leisure that might usefully be used to determine the boundaries of 'leisure property'.

\section{LEISURE, CULTURE AND THE CREATIVE INDUSTRIES}

Concomitant with 'leisure' becoming a recognised sector of property activity, its forms of organisation have become increasingly hybridised, such that the traditional demarcation between activity types (sport, recreation, the arts etc) and providers (public, private and voluntary) is becoming less evident. ${ }^{6}$ This has been reflected in government, with the Department of Culture, Media and Sport (DCMS) now having a remit covering sport, recreation, the arts, media and gambling. As such, the term 'leisure' has lost currency in favour of more inclusive terms, particularly 'culture'. This is particularly the case with regional development agencies and local government, which have increasingly sought to align themselves with the remit of the DCMS under the banner of cultural and creative industries. ${ }^{7}$ Apart from bureaucratic hygiene this signals an important conceptual difference between 'leisure'broadly understood as an individually inspired consumptive activity - and culture, which has a much stronger connection to 


\section{Consumptive activities}

\section{Defining the cultural and creative industries}

production and the use of space and resources. Thus, as alluded to in the aims of the Journal, the conceptual connection between retail and leisure property is understood to be much more associated with consumption and consumptive activities than it is with broader and inclusive definitions of either term. It also implies a rather strategic understanding of consumptive activities, such that they are separated from any form of production or other industrial process.

While this description and understanding of leisure property may sit well with the interests of commercial property investors and managers, it effectively excludes much property and associated activity also commonly understood to have connections with leisure. Perhaps the prime example is outdoor recreation, with its very different constructs of property, ${ }^{8}$ although it could equally be extended to urban open space, or to the more sporting activities associated with gymnasia, swimming pools and other such provisions. It also rather avoids property associated with the development and exploitation of intellectual property rights and other forms of creativity.

In contrast to the narrow, commercially driven consumption focus of 'leisure property', the productivist construct of cultural and creative industries offers a broader and more inclusive, if not necessarily less contested, means of defining property related to leisure activity and usage. The UNESCO (United Nations Education, Scientific and Cultural Organisation) definition of the cultural industries offers a starting point:

\section{those industries that combine the creation, production and commercialisation of contents which are intangible and cultural in nature. These contents are typically protected by copyright and they can take the form of goods or services."9}

This is conceptually akin to the definition adopted by the Cultural Industries Task Force (CITF):

\section{'Those activities which have their origin in individual creativity, skill and talent and which have a potential for wealth and job creation through the generation and exploitation of intellectual property. ${ }^{, 10}$}

Both definitions proceed to list a series of industries which relate to these broad categories, including printing, publishing and multimedia, audio-visual, phonographic and cinematographic productions, crafts and design, architecture, visual and performing arts, sports, manufacturing of musical instruments, advertising and cultural tourism. In developing such a definitional approach, both UNESCO and the CITF are tacitly subscribing to a "cultural production' model of leisure and associated activity. A similar focus can be found elsewhere, in the implied 'value of culture' model used by the Learning and Skills Council, ${ }^{11}$ for example. While being less 
Industrial classifications

\section{Cultural industries production system}

concerned with production (or consumption) per se, its focus on economic activity reflects a broader remit than that related to consumption alone.

Both the cultural production and value of culture approaches are based on the identification of enterprises and economic activity according to the Standard Industrial Classification (SIC) used by the Office for National Statistics. Unfortunately, while reflecting the development of industrial and manufacturing enterprises in the UK, through a meticulously separated list of manufacturing roles and occupations, the SIC has failed to grasp the increasing diversity and complexity of service and cultural occupations. As a result, the SIC is an inadequate tool for separating and describing the functions related to the cultural and creative industries. Despite their limitations, however, many attempts have been made to utilise the SIC codes, largely on the basis that there is currently little viable alternative. ${ }^{12}$ Andy Pratt, for example, has usefully divided up the codes according to a value chain, which focuses upon the economic features of cultural and creative activity along the continuum of production-distribution-consumption. ${ }^{13}$ This approach has been labelled the 'cultural industries production system', although it might equally be referred to as the 'cultural industries value chain'. It is illustrated in Figure 1. ${ }^{14}$

Included on the production side are forms of individual and collective creative activity that utilise talents and skills often characterised by their innovation and originality. In many cases these activities lead to the creation of intellectual property in the form of copyright. This includes forms of performance and their management (editing and production) and the creation (or preservation) of designs, sounds, images and texts. The model then includes a group of businesses responsible for the "production of the means of production', which takes into account manufacturing
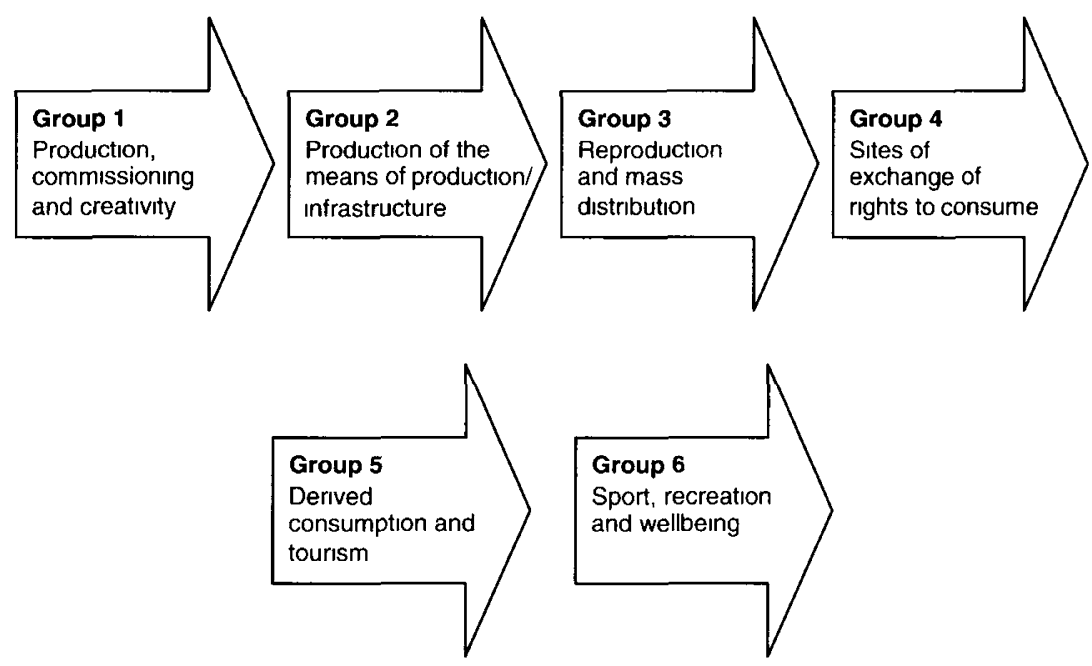

Figure 1: Pratt's 'cultural industries production system' 


\section{Employment in the cultural industries}

inputs in relation to the production of cultural goods.

'Reproduction and mass distribution' are also included, which take account of a large swathe of the cultural industries, from printing to publishing. 'Sites of exchange of rights to consume' is included as a necessary category to take account of the market/audience end of the cultural industries value chain (and the set of activities housed in what is conventionally understood as leisure property). Pratt also includes other parts of the cultural industry, including sport, recreation and wellbeing, and derived consumption and tourism (including restaurants, cafés, visitor attractions and accommodation).

Pratt has applied this chain to his categorisation of employment types for the cultural industries, drawn from the SIC 1992. Utilising this approach, this paper proposes a more comprehensive and contemporary breakdown using the 2003 two-digit and four-digit SIC codes (see Table $1^{15}$ ).

Table I: Standard Industrial Classifications of the cultural industries

\begin{tabular}{|c|c|c|}
\hline SIC (2003) industry description & SIC (2003) & SIC 80 \\
\hline \multicolumn{3}{|l|}{$\begin{array}{l}\text { Group I Production: Original production, commissioning } \\
\text { and directing }\end{array}$} \\
\hline Manufacture of knitted and crocheted hosiery & 17.71 & 4363 \\
\hline Manufacture of knitted and crocheted pullovers, cardigans etc & 17.72 & 4363 \\
\hline \multirow[t]{2}{*}{ Manufacture of leather goods } & 18.10 & 4532 \\
\hline & & 4533 \\
\hline \multirow[t]{4}{*}{ Manufacture of workwear } & 18.21 & 4352 \\
\hline & & 4533 \\
\hline & & 4534 \\
\hline & & 4536 \\
\hline \multirow[t]{4}{*}{ Manufacture of other outerwear } & 18.22 & 4531 \\
\hline & & 4532 \\
\hline & & 4533 \\
\hline & & 4536 \\
\hline \multirow[t]{4}{*}{ Manufacture of underwear } & 18.23 & 4533 \\
\hline & & 4535 \\
\hline & & 4536 \\
\hline & & 4539 \\
\hline \multirow[t]{6}{*}{ Manufacture of other wearing apparel and accessories } & 18.24 & 4363 \\
\hline & & 4537 \\
\hline & & 4538 \\
\hline & & 4539 \\
\hline & & 4560 \\
\hline & & 4563 \\
\hline \multirow{2}{*}{ Dressing and dyeing of fur; manufacture of articles of fur } & 18.30 & 4560 \\
\hline & & 4410 \\
\hline Manufacture of footwear & 19.30 & 4510 \\
\hline Letting of conference and exhibition centres & $70.20 / 1$ & 8500 \\
\hline Computer games desıgn & 72.22 & 8394 \\
\hline Architectural engineering activities and related technical consultancy & 74.20 & 8370 \\
\hline Advertısing & 74.40 & 8380 \\
\hline Photographic activities & 74.81 & 9890 \\
\hline \multirow[t]{3}{*}{ Speciality design actıvities } & 74.87 & 9760 \\
\hline & & 4510 \\
\hline & & 4395 \\
\hline Activities of exhibition and fair organisers & $74.87 / 3$ & 8395 \\
\hline Activities of conference organisers & $74.87 / 4$ & 8395 \\
\hline $\begin{array}{l}\text { Other business activities NEC (Including fashion artist and literary } \\
\text { and theatrical agents) }\end{array}$ & $74.87 / 9$ & 8395 \\
\hline $\begin{array}{l}\text { Technical and vocational secondary education (covering performing and } \\
\text { visual arts teachers) }\end{array}$ & 80.22 & 9330 \\
\hline
\end{tabular}


Table I: Contınued

\begin{tabular}{|c|c|c|}
\hline SIC (2003) industry description & $\operatorname{sic}(2003)$ & SIC 80 \\
\hline Motion picture and video production & 92.11 & 9711 \\
\hline Motion picture and video distribution & 92.12 & 9711 \\
\hline Motion picture projection & 92.13 & 9711 \\
\hline Radio and television activities & 92.20 & 9741 \\
\hline \multirow[t]{2}{*}{ Live theatrical presentations } & $9231 / 1$ & 9741 \\
\hline & & 9760 \\
\hline Artistic and literary creation and interpretation & $92.31 / 9$ & 9760 \\
\hline \multirow[t]{2}{*}{ Operation of arts facilities } & 92.32 & 9741 \\
\hline & & 9791 \\
\hline Other entertainment activities NEC & 92.34 & 9791 \\
\hline News agency activities & 92.40 & 8395 \\
\hline Motion picture, television and other theatrical casting & $9272 / 1$ & 9791 \\
\hline \multicolumn{3}{|l|}{ Group 2 Infrastructure: Production of the means of production } \\
\hline Hardware consultancy & 72.10 & 8394 \\
\hline Software consultancy and supply & 72.20 & 8394 \\
\hline Other software consultancy and supply & 72.22 & 8394 \\
\hline \multirow[t]{2}{*}{ Data processing } & 72.30 & 8394 \\
\hline & & 8395 \\
\hline Database activities & 72.40 & 8394 \\
\hline Other computer-related activities & 72.60 & 8394 \\
\hline Printıng ink & $24.30 / 2$ & 2552 \\
\hline Photographic materials and chemicals & 26.64 & 2591 \\
\hline Prıntıng, bookbınding and paper-goods machınery & 29.56 & 3276 \\
\hline Radio and electronic capital goods & 33.20 & 3443 \\
\hline $\begin{array}{l}\text { Active components, subassemblies and components mainly for consumer } \\
\text { goods }\end{array}$ & 32.20 & 3453 \\
\hline Electronic consumer goods, other electronic equipment NEC & 32.10 & 3454 \\
\hline Photographic and cınematographic equipment & $33.40 / 3$ & 3733 \\
\hline Musical instruments & 36.30 & 4920 \\
\hline Photographic processing laboratories & $74.81 / 4$ & 4930 \\
\hline \multicolumn{3}{|l|}{ Group 3 Distribution: Reproduction and mass distribution } \\
\hline \multirow[t]{2}{*}{ Publishing of books } & 2211 & 4753 \\
\hline & & 4754 \\
\hline Publishıng of newspapers & 22.12 & 4751 \\
\hline Publishing of journals and periodicals & 22.13 & 4752 \\
\hline \multirow[t]{3}{*}{ Publishing of sound recordings } & 22.14 & 3452 \\
\hline & & 4754 \\
\hline & & 3276 \\
\hline Other publishing & 22.15 & 4754 \\
\hline Printing of newspapers & 22.21 & 4751 \\
\hline \multirow[t]{3}{*}{ Printing NEC } & 22.22 & 4753 \\
\hline & & 4754 \\
\hline & & 4723 \\
\hline Bookbınding & 22.23 & 4754 \\
\hline \multirow[t]{3}{*}{ Pre-press activities } & 22.24 & 4754 \\
\hline & & 4734 \\
\hline & & 3276 \\
\hline Ancillary operations related to printing & 22.25 & 4754 \\
\hline Reproduction of sound recording & 22.31 & 3452 \\
\hline Reproduction of video recording & 22.32 & 3452 \\
\hline Reproduction of computer media & 22.33 & 3452 \\
\hline Publishing of software & 72.21 & 8394 \\
\hline \multicolumn{3}{|l|}{ Group 4 Consumption: Sites of exchange of rights to consume } \\
\hline Retall of electrical household appliances and radio and TV goods & 52.45 & 6480 \\
\hline Retail sales in commercial art galleries & $52.48 / 6$ & 6480 \\
\hline \multirow[t]{2}{*}{ Other retall sales in specialised stores } & $52.48 / 9$ & 6540 \\
\hline & & 6480 \\
\hline Retail sales of antiques, including antique books in stores & $52.50 / 1$ & 6480 \\
\hline Retall sales of second-hand goods in stores & 52.50 & 6540 \\
\hline Library and archives activities & 92.51 & 9770 \\
\hline Museum activities & $92.52 / 1$ & 9770 \\
\hline
\end{tabular}


Table I: Contınued

\begin{tabular}{|c|c|c|}
\hline SIC (2003) industry description & SIC (2003) & SIC 80 \\
\hline \multicolumn{3}{|l|}{ Group 5 Derived consumption and tourism } \\
\hline Hotels and motels & 55.10 & 6650 \\
\hline Youth hostels and mountain refuges & 55.21 & 6670 \\
\hline Camping sites, including caravan sites & 55.22 & 6670 \\
\hline Holiday centres and holiday villages & $55.23 / 1$ & 6670 \\
\hline Other self-catering holıday accommodation & $55.23 / 2$ & 6670 \\
\hline Other tourist or short-stay accommodation & $55.23 / 9$ & 6670 \\
\hline Licensed restaurants & $55.30 / 1$ & 6611 \\
\hline Unlicensed restaurants and cafés & $55.30 / 2$ & 6611 \\
\hline Take-away food shops & $55.30 / 3$ & 6612 \\
\hline Licensed clubs & $55.40 / 1$ & 6630 \\
\hline Independent public houses and bars & $55.40 / 2$ & 6620 \\
\hline Tenanted public houses and bars & $55.40 / 3$ & 6620 \\
\hline Managed public houses and bars & $53.40 / 4$ & 6620 \\
\hline Activities of travel agents & $6630 / 2$ & 6620 \\
\hline Activities of tour guides & $66.30 / 3$ & 6620 \\
\hline Other tourist assistance activities & $66.30 / 9$ & 6620 \\
\hline $\begin{array}{l}\text { Business and management consultancy activities NEC (Including tourism } \\
\text { development consultancy) }\end{array}$ & $74.14 / 9$ & 8395 \\
\hline \multicolumn{3}{|l|}{ Group 6 Sport, recreation and wellbeing } \\
\hline Primary education (playwork) & 80.10 & 9320 \\
\hline $\begin{array}{l}\text { Activities of other membership organisations NEC (eg associations that } \\
\text { cover the pursuit of cultural activity or hobbies and youth groups) }\end{array}$ & 91.33 & 9690 \\
\hline Fair and amusement park activities (including preservation of old railways) & 92.33 & 9791 \\
\hline Dance halls, discotheques and dance instructor services & $92.34 / 1$ & 9791 \\
\hline \multirow[t]{2}{*}{ Preservation of historical sites and bullings } & $92.52 / 2$ & 9770 \\
\hline & & 9690 \\
\hline Botanical and zoological gardens and nature reserve activities & 92.53 & 9770 \\
\hline Operation of ice rınks and roller-skatıng rınks & $92.61 / 1$ & 9791 \\
\hline Operation of other sports arenas and stadiums NEC & $92.61 / 9$ & 9791 \\
\hline Activities of racehorse owners & $92.62 / 1$ & 9791 \\
\hline Other sporting activities NEC & $92.62 / 9$ & 9791 \\
\hline \multirow[t]{2}{*}{ Other recreational activities, including gambling and betting activities } & 92.70 & 9791 \\
\hline & & 9111 \\
\hline Physical wellbeing activities & 93.04 & 9820 \\
\hline $\begin{array}{l}\text { Other service activities NEC (eg artists' model, master of ceremonies, } \\
\text { pavement artist, tattooist, toast master) }\end{array}$ & 9305 & 9890 \\
\hline
\end{tabular}

NEC: not elsewhere classified.

\section{Breadth of activities}

While demonstrating the breadth of activities in the cultural and creative industries sector, Table 1 does highlight the relative importance of those subsectors conventionally related to leisure activity (groups $4-6$, where there is a direct relationship between audience and performance). ${ }^{16}$ Many of these subsectors have property requirements that are addressed by what is conventionally understood as 'leisure property'. Table 1 also implies that the cultural industries can be placed along a continuum where, on the one side, the audience or market comes to the content (the cultural products and services) through sites of consumption and outlets for cultural activity and, on the other, a large section of the cultural industries works to deliver content to the market, through distribution and reproduction (see Figure 2). ${ }^{17}$

From Figure 2 it is apparent that the primary relationship 


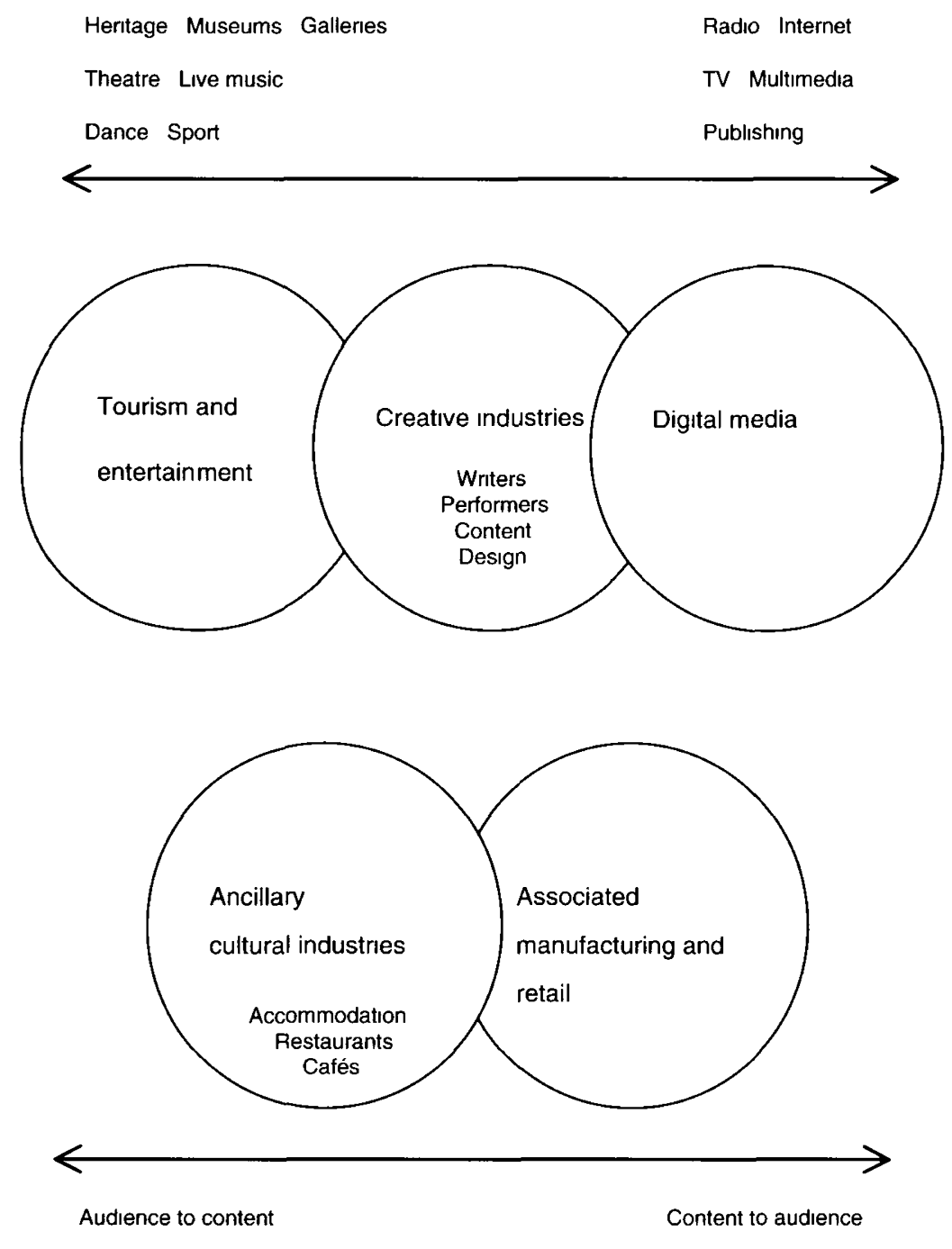

Figure 2: The cultural industries

\section{Serious and casual leisure}

between culture/leisure and its property requirements is the value flow (audience/consumer to content, or content to audience/ consumer). Under this construct, 'leisure property' extends far beyond hotels, catering, clubs and the like, to encompass a much broader and more diverse sector linked directly through its relationship between production and consumption. This reflects work conducted by Bob Stebbins, in which he has distinguished between the constructs of serious and casual leisure. ${ }^{18}$ For Stebbins, casual leisure is largely consumption-oriented, being immediately intrinsically rewarding and requiring little preparation and training. As such it is consistent with narrow commercial understandings of leisure and its property requirements. In contrast, serious leisure 'is the systematic pursuit of an ... activity that participants find so substantial and interesting that ... they launch themselves on a career centred on acquiring and expressing its special skills, knowledge and experience'. ${ }^{19}$ 
Value chain

\section{Looking beyond retail}

Essentially, the division between production and consumption is set out in Figure 2. Under this construct, conventional understandings of leisure property relate primarily to casual consumerist activities in which instant gratification is paramount. In contrast, the broader field of cultural production encompassed in serious leisure maintains the consumerist focus while introducing both production and distribution, and - by implication at least the ensuing property requirements.

\section{DISCUSSION}

The contention at the start of this paper was that conventional understandings of 'leisure property' fail to convey the full breadth of occupier requirements for property in which leisure-related activities take place. This reflects a narrow and increasingly outmoded understanding of 'leisure' and an equally narrow association of leisure activity with consumptive activities dominated by retailing. While there is some validity in both these arguments, they fail to reflect a more contemporary - and bureaucratic understanding of leisure activity as part of a bigger and increasingly significant cultural and creative sector. While certainly encompassing the activities conventionally understood as 'leisure', this sector connects consumption with production, distribution and reproduction in a value chain recognisably similar to that found in other industrial sectors.

There is thus a case for arguing that current constructs of leisure property are too parochial and restricted by their limitation to consumptive activities. It is here that the links made between leisure and retail are misleading. While retail outlets are part of a value chain ostensibly similar to the one described for leisure and culture, it is commonly accepted that retail is but one way in which goods reach consumers. It is thus a subsector of a larger supply (value) chain related to the manufacture, supply and distribution of goods. In contrast, leisure/culture reflects the entire value chain.

In conclusion, therefore, there is a clear need to rethink the definition of leisure property to ensure that it reflects the full range of property requirements of those working in the industry. There is also a need for caution in attempting to make linkages between different property forms. Most leisure-related activity reflects a nexus between production, reproduction, distribution and consumption, such that many sites fulfil multiple functions. For example, some sites of production (craft workshops, for example) are also sites of consumption, while sports stadia incorporate production, reproduction and consumption. Of course, consumption activity in leisure has many connections to similar activities in the wider sphere of retail - and indeed may be indistinguishable from retail. Yet the argument remains that leisure, as a category of human activity, has property requirements that extend far beyond consumption and, thus, retail. 


\section{References}

1 Ravenscroft, N. (2000) 'The vitality and viability of town centres', Urban Studtes, Vol. 37, No. 13. pp. 2533-2549; Ravenscroft, N., Reeves. J. and Rowley, M. (2000) 'Leisure, property and the viability of town centres', Environment and Planning, Vol. 32, No. 8, pp. 1359-1374: Sayce, S. (1996) 'Leisure property and the question of profit'. Journal of Property Finance, Vol. 6, No. 1, pp 7-27.

2. Davies, H W E., Ravenscroft, N., Bishop, K. and Gosling, J. (1991) The Planning System and Large Scale Leisure and Tourism Development, National Economic Development Office, London, UK; Evans, G. (1998) 'Urban leisure. Edge city and the new leisure perıphery', in Collins, M. F. and Cooper, I. S. (eds) Leisure Management Issues and Applications, CAB International. Wallingford. UK, pp. 113-137.

3 Willımson. H. (1994) 'Law affecting leisure property', in Marshall. H. and Willamson, H. (eds) Law and Valuation of Leisure Property, Estates Gazette, London, UK, pp 1-75; Egan, D. (1997) 'An economic analysis of out of town leisure development and PPG', paper presented at an ESRC Urban and Regional Economics Group seminar, Chester University College, UK, 2-4 July.

4. There are, of course, a number of exceptions to this generalisation Morley, S. and Evans, C. (2000) 'The future for leisure property in the UK', Journal of Letsure Property' Vol. 1, No. 1, pp. 18-26, Butter, I. (2001) 'Plannıng ahead' Understanding the government's future leisure planning policy', Journal of Leisure Property, Vol 1. No. 4. pp. 337-349: Sayce, S. and McIntosh, A. (2002) 'Planning for lessure: Time for a radical rethınk or just a slight adjustment?', Journal of Lelsure Property, Vol 2, No. 3, pp 254 281; Fallon. J (2003) 'New thinkıng on health and fitness', Journal of Retall and Leisure Property, Vol. 3, No 4, pp. 307-313

5 Sayce and McIntosh, $t b t d$.

6. Slack, T. (1999) 'Changing boundaries and new management implications for leısure organizatıons', in Jackson. E. L and Burton. T. L (eds) Leisure Studies Prospects for the Twenty-first Century. Venture Publıshing, State College. PA, pp. 399-413.

7. Ravenscroft. N. (2002) "A comparison of the strategy documents of the regional cultural consortia in England, report to South East England Cultural Consortium, Chelsea School, University of Brighton: Attchison, C and Evans, T (2003) 'The cultural Industries and a model of sustainable regeneration: Manufacturing "pop" in the Rhondda valley, South Wales', Managing Leisure, Vol. 8, No. 3, pp. 133-144; Ravenscroft, N. and Tomlinson, A. (2003) 'Developing the cultural agenda. The sociospatial dimensions of the regional cultural strategies in England', in Snape. R., Thwattes. E. and Williams, C. (eds) Access and Inclusion in Letsure and Tourism, Publication 81, Leisure Studies Association. Eastbourne. UK, pp. 3-22.

8 Broadhurst, R. (2001) Managing Environments for Lelsure and Recreation, Routledge. London, UK.

9 Unted Nations Educational, Scientıfic and Cultural Organizatıon (UNESCO) (2004) Culture, Trade and Glohalisatıon. Questions and Answers, UNESCO, Parıs, France, available at www.unesco org.

10. Department of Culture, Medıa and Sport (2001) Creatwe Industries Mapping Document. DCMS, London, UK

11 Sussex Learnıng and Skills Councl (2002) Workforce Development Plan for Sport and Recreation. Sussex Learning and Skills Council, Brighton, UK.

12. Cornford, J., Charles, D., Wood. P., Robson. L., Chatterton, P. and Belt, V. (2001) Culture Cluster Mapping and Analysis. A Draft Report for One North East, CURDS. Newcastle-upon-Tyne. UK, Papworth, R. M. (2002) 'Workforce development strategy Cultural and creatıve sector', final report to Sussex Learnıng and Skılls Council,

Brighton. UK, Papworth, R. M (2002) 'Workforce development strategy - Hospitality and tourism', final report to Sussex Learning and Skılls Council. Brighton, UK, Pratt, A (1997) 'The cultural industries production system: A case study of employment change in Britain. 1984-1991', Environment and Planning, Vol. 29, No. 11, pp. 1953-1974, Pratt, A (2004) "The cultural economy: A call for spatialized "production of culture" perspectıves", International Journal of Cultural Studies, Vol. 7, No. 1, pp. 117-128, David Powell Associates (2001) Creative and Cultural Industries - An Economic Impact Study for South East England, SEEDA;SEECC, Guildford. UK

13. Pratt (1997), ihid. 
14. Ibid.

15. Ibud.; Office for National Statistics (2003) Indexes to the UK Standard Industrial Classificattons of Economic Actlvittes 2003, Office for National Statıstics, London, UK: Department for Education and Skills (2002) An Assessment of Skills Needs in Tourism and Cultural Industries, DfES, Nottingham, UK, available at www.dfes gov.uk/ skillsdıaloguereports; SPRITO (2001) Workforce Development Plan. Sport and Recreation Sector, National Trainıng Organisation for Sport, Recreation and Allied Occupations (SPRITO), London, UK, available at www.sprito.org.uk/index701.htm; Sector Skills Development Agency (2005) Sector Skill Matrix, SSDA, Wath-upon-Dearne, UK available at www.ssdamatrix.org.uk/mail.asp

16 Cornford et al., ref. 12 above.

17 Adapted from $i b l d$.

18 Stebbıns, R. (1999) 'Serious leisure', in Jackson, E. L. and Burton, T. L. (eds) Lelsure Studies. Prospects for the Twenty-first Century, Venture Publishing. State College, PA, pp. 69-80; Stebbins, R. (2005) 'Project leisure: A conceptual statement', Leisure Studies, Vol. 24, No. 1, pp. 1-11.

19. Stebbıns, R. (1992) Amateurs, Professionals and Serious Leisure, McGill-Queen`s University Press, Montreal. Canada. 